\title{
Remediation of DOE Hazardous Waste Sites: Planning and Integration Requirements
}

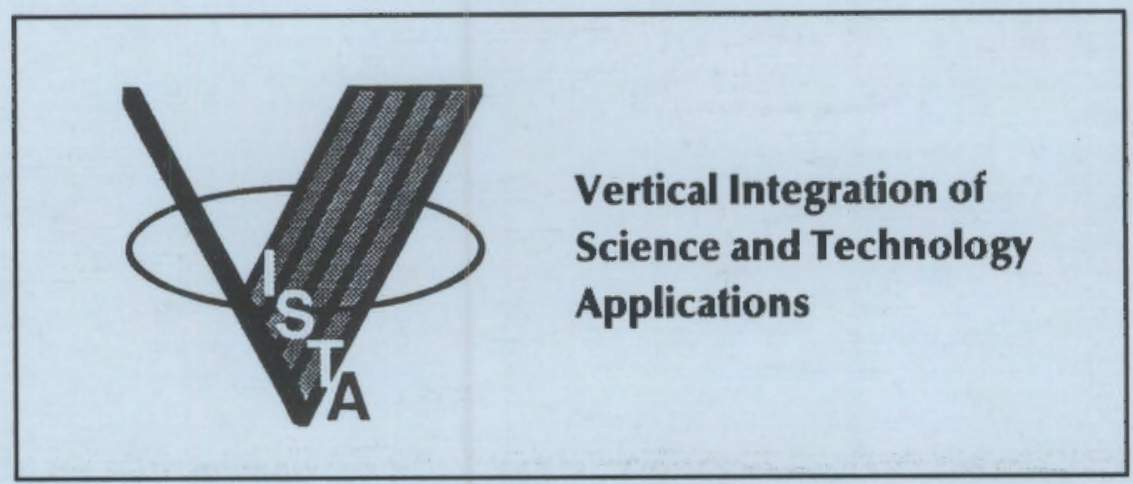
C. A. Geffen
M. R. Siegel
B. A. Garrett
J. F. Keller
C. E. Cowan

September 1989

Prepared for the

U.S. Department of Energy

under Contract DE-AC06-76RL.O 1830

Pacific Northwest Laboratory

Richland, Washington 99352 


\title{
DISCLAIMER
}

This program was prepared as an account of work sponsored by an agency of the United States Government. Neither the United States Government nor any agency thereof, nor Battelle Memorial Institute, nor any or their employees, makes any warranty, expressed or implied, or assumes any legal liability or responsibility for the accuracy, completeness, or usefulness of any information, apparatus, product, or process disclosed, or represents that its use would not infringe privately owned rights. Reference herein to any specific commercial product, process, or service by trade name, trademark, manufacturer, or otherwise, does not necessarily constitute or imply its endorsement, recommendation, or favoring by the United States Government of any agency thereof, or Battelle Memorial Institute. The views and opinions of authors expressed herein do not necessarily state or reflect those of the United States Government or any agency thereof.

\author{
PACIFIC NORTHWEST LABORATORY \\ operated by \\ BATTELLE MEMORIAL. INSTITUTE \\ for the \\ UNITED STATES DEPARTMENT OF ENERGY \\ under Contract DE-AC06-76RLO 1830
}

Printed in the United States of America

Available to DOE and DOE contractors from the

Office of Scientific and Technical Information, P.O. Box 62, Oak Ridge, TN 37831; prices available from (615) 576-8401. FTS 626-8401.

Available to the public from the National Technical Information Service,

U.S. Department of Commerce, 5285 Port Royal Rd., Springfield, VA 22161.

NTIS Price Codes, Microfiche A01

\begin{tabular}{|c|c|}
\hline \multicolumn{2}{|c|}{ Printed Copy } \\
\hline Pages & $\begin{array}{l}\text { Price } \\
\text { Codes }\end{array}$ \\
\hline $001-025$ & $\mathrm{~A} 02$ \\
\hline $026-050$ & $\mathrm{~A} 03$ \\
\hline $051-075$ & $\mathrm{~A} 04$ \\
\hline $076-100$ & A05 \\
\hline $101-125$ & A06 \\
\hline $126-150$ & A07 \\
\hline 151.175 & A08 \\
\hline $176-200$ & $\mathrm{~A} 09$ \\
\hline $201-225$ & A10 \\
\hline $226-250$ & A11 \\
\hline $251-275$ & A12 \\
\hline $276-300$ & A13 \\
\hline
\end{tabular}


Remediation of DOE Hazardous Waste Sites:

Planning and Integration Requirements
C. A. Geffen
B. A. Garrett
C. E. Cowan
M. R. Siegel
J. F. Keller

September 1989

Prepared for

the U.S. Department of Energy

under Contract DE-AC06-76RLO 1830

Pacific Northwest Laboratory

Richland, Washington 99352 



\section{Preface}

The Vertical Integration of Science, Technology, and Applications (VISTA) project is an initiative to develop and deploy information systems, in the form of software or softwarel hardware products, to broad segments of various markets. VISTA is being supported at the Pacific Northwest Laboratory (PNL) by the US. Department of Energy (DOE). VISTA products will provide users with mechanisms for accessing PNL-resident information about complex scientific or engineering problems, such as remediation of DOE hazardous waste sites.

As a DOE-supported laboratory, PNL generates and acquires information in certain application areas; for example, in environmental modeling. This information historically has received limited distribution; typically, it is delivered to the client and published in the open literature. VISTA is an effort to render such information useful in solving practical problems for other customers.

The first VISTA product is in the environmental market because of PNL's experise and DOE's recognized needs in this area. As currently envisioned, the first product is a system that will provide DOE and its contractors integrated support for performing and documenting hazardous waste site investigations, for analyzing the data obtained from the site, and for selecting remedial alternatives to meet evolving environmental regulations.

The objectives of VISTA during its developing stages have been to analyze the market and specify a computer architecture that will be implemented in VISTA products. This document supports the former objective; it summarizes the information management problem in the remediation of DOE hazardous waste sites.

VISTA is expected to evolve, as the market for VISTA applications changes and as computer systems advance. This document, as part of the VISTA "library," serves as a reference for the thinking that went into developing the first VISTA product and as an information base for continued development. 


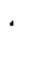




\section{Executive Summary}

The U.S. Department of Energy (DOE) is faced with an immense challenge in effectively implementing a program to mitigate and manage the environmental impacts created by current operations and from past activities at its facilities. The current regulatory framework and public interest in the environmental arena have made operating DOE facilities in an environmentally responsible manner a compelling priority.

This paper provides information on the results of a project funded by DOE to obtain a better understanding of the regulatory and institutional drivers in the hazardous waste market and the costs and timeframes required for remediation activities.

Few realize that before remediating a hazardous waste site, a comprehensive planning process must be conducted to characterize the nature and extent of site contamination, calculate the risk to the public, and assess the effectiveness of various remediation technologies. The U.S. Environmental Protection Agency (EPA) and others have found that it may take up to 7 years to complete the planning process at an average cost of $\$ 1.0$ million per site. While cost information is not yet available for DOE sites, discussions with hazardous waste consulting firms indicate that average characterization and assessment costs will be 5 to 10 times this amount for DOE sites. The higher costs are expected because of the additional administrative requirements placed on DOE sites, the need to handle mixed wastes, the amount and extent of contamination at many of these sites, and the visibility of the sites.

About half of the cost of the planning, characterization, and assessment activities is related to collecting, analyzing, documenting, and reporting information. The information required to complete the characterization and assessment activities for a single hazardous waste site can be voluminous. Between major documents required for the process, and the backup data and analyses required to support the administrative records, DOE could face the handling and storage of up to 2.5 million pages of information each year. This figure is based on the number of DOE sites and on previous experience at Department of Defense $(D O D)$ sites thought to be representative of the complex federal sites DOE will be addressing.

The information management challenge presented by waste site cleanup activities goes beyond merely dealing with the large quantity of data that will be generated. The number of DOE sites, their location in different regions, and the cadre of contractors that will be involved raise other information management issues that DOE will need to address. Among these are

- evaluating the benefits of a uniform approach across sites and within sites with respect to data validation and quality assurance, decision making and documenting, and reporting

- providing efficient access to and sharing of information among sites to facilitate knowledge and technology transfer and to avoid costly duplication of effort

- responding to requests for information that require aggregating information across sites from a variery of constituents (e.g., Congress, the media, public interest groups) in a timely and credible manner. 
A technically credible information management system applied consistently across all DOE facilities would enable DOE to conduct its waste remediation program in a cost-effective, timely manner while instilling public confidence in the process. A standardized approach to information management would greatly facilitate negotiations with the regulatory agencies and the public, as well as minimize duplication of costs among sites and contractors in this area. The most effective information management system would most likely combine some centralized elements with others that are decentralized to the individual sites. EPA experience suggests that some level of centralized management and guidance for the format and quality assurance of the information in the system would be beneficial.

Through automation, the best features of the centralized and decentralized approaches can be combined. With an automated system, each site would maintain its own site-specific information in a standardized format that would facilitate data retrieval and integration with other sites. Central data bases would contain information relevant to all sites (regulations, cleanup criteria, technology data). An on-line system could be provided to allow the sites to access the central data bases and to query the individual site data bases from a central source to facilitate compiling cross-site reports. This would enable DOE to respond to ad hoc requests for information more quickly and with assurance that the data are consistent with what is being reported by the sites. 


\section{Contents}

Preface

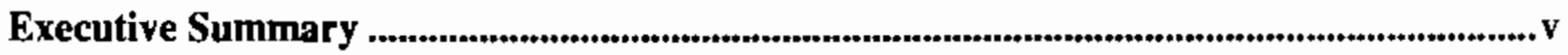

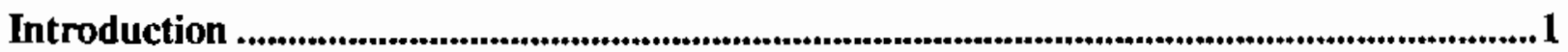

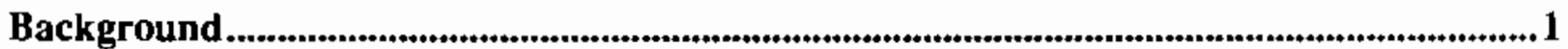

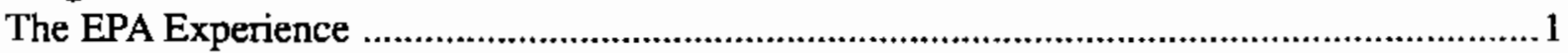

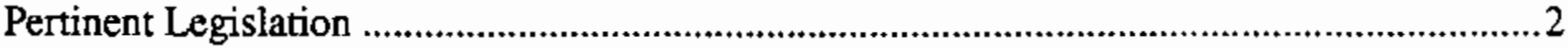

Site Characterization and Assessment ..........................................................................................2

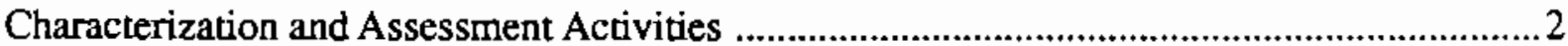

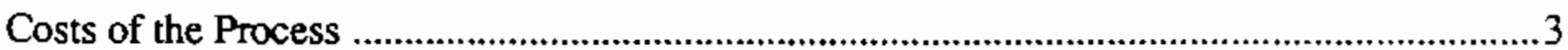

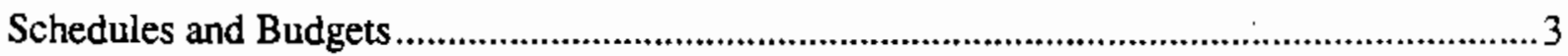

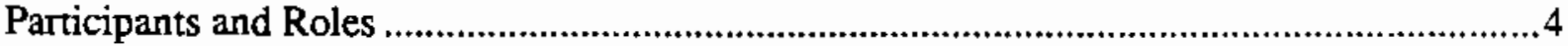

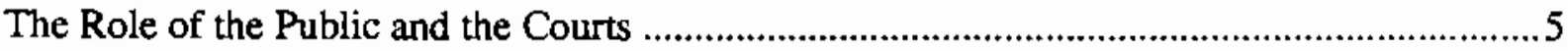

Information Management: The Magnitude of the Problem ...............................................5

Information Management: The Nature of the Problem ....................................................6

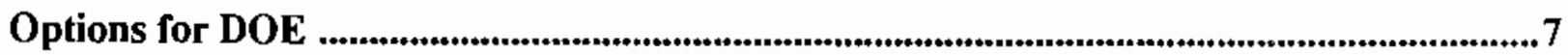

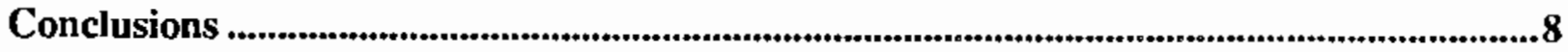

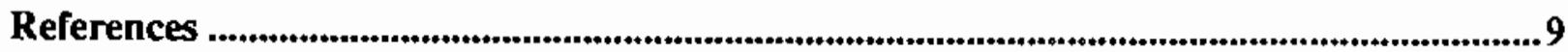

APPENDIX A: Description of CERCLA and RCRA ....................................................13

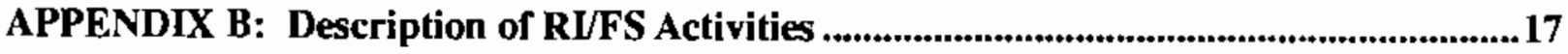


$+$

\section{$-$}




\section{INTRODUCTION}

The remediation of sites contaminated with hazardous or mixed (containing hazardous and radioactive constituents) wastes will be one of the more visible and expensive activities required by existing environmental regulations. Environmental cleanup of DOE facilities will require a multibillion-dollar program extending over a time period of 20 to 50 years or more. Successful accomplishment of program objectives will require consideration of not only technical issues, but perhaps more importantly, regulatory and institutional constraints. Because these program objectives must be accomplished with limited budgets, a systematic, costeffective approach must be developed to address the technical issues and the regulatory and institutional constraints.

Before remediating a site, DOE and EPA, along with other regulatory agencies and the public, must agree on how to proceed with cleanup. Reaching a decision may take from 2 to 7 or more years. Given the public's pressure, through Congress and various public interest groups, on DOE to show immediate results, it is imperative to seek ways to reduce the time and cost of the site characterization and decision-making process, without sacrificing quality and credibility.

To reach a cleanup decision, site characterization and assessment must be conducted to determine the nature and extent of site contamination, calculate the risk to the public, and assess the effectiveness of various remediation technologies. This involves collecting and analyzing a vast amount of technical data and communicating a broad range of information based on these data to a variety of audiences. The timing and cost of this process can be reduced significantly by a program to manage and use the information generated by the planning and assessment activities that incorporates regulatory and institutional (including public) concems. A new approach to the collection and management of environmental data and program information is likely to be required to handle the vast amount of information that will be generated by these activities.

This report provides background information on the regulatory and institutional issues associated with the characterization and assessment process, describes the site characterization and assessment activities that must be conducted before actual site remediation can take place, indicates the magnitude of DOE's information management problem, identifies the nature of the information and data management problem associated with site cleanup, and recommends an approach for dealing with this issue.

This work was conducted by Pacific Northwest Laboratory (PNL) ${ }^{(\alpha)}$ as part of a project funded by DOE to obtain an understanding of the regulatory and institutional drivers in the hazardous waste market and the costs of remediation activities.

\section{BACKGROUND}

The problem of cleaning up hazardous waste sites is fairly new to DOE. The EPA, however, in its role as manager of the Superfund program, has been dealing with this problem since the authorization of the Comprehensive Environmental Response, Compensation, and Liability Act (CERCLA) [1] in 1980. Therefore, it is helpful to examine EPA's experience to gain perspective on the magnitude and complexity of the task faced by DOE. In addition, it is important to understand the statutes and regulations that will govem the cleanup process.

\section{The EPA Experience}

The EPA has been much criticized for its handling of the Superfund program [2-6]. Typically, this criticism centers around the prolonged schedules associated with achieving remediation at a site, the lack of standardization in site evaluation and reporting, and the lack of uniform quality assurance programs among regions, all of which have eroded public confidence in EPA. Some of these problems stem from a shortage of qualified staff, which has forced EPA to rely on a number of contractors, each of which has its own methods of approaching the site planning, characterization, and assessment process. As a result, cleanup goals have not been set or applied consistently across sites. This decentralized operation has made it difficult, if not impossible, for EPA to provide consistent reponing on the status of cleanup and enforcement activities and the progress of the program across the nation.

When the federal haxardous waste program was initiated, the amount of paperwork was

(a) Pacific Northwest Laboralory is operaled for the U.S. Department of Energy by Batrelle Memorial Instituce. 
sufficiently small to allow the program managers to keep track of the enforcement activities. As the program has grown, however, so have the concems about information and data management and the need for standardization. Currently, data and information management has become an overriding concem in the Superfund program. Recent EPA panels have recommended that more emphasis should be placed on data collection efforts and on making the most effective use of the data that are collected.

Information management systems for this purpose are only now in the process of being developed. For example, several EPA regions are beginning to require sites to prepare data management plans that indicate how the data will be stored and to ensure that the data bases are consistent at the regional level. The EPA hopes eventually to make the regional data bases compatible, enabling sharing of experience-based information among regions. Cumently, information sharing among regions relies heavily on summary reports prepared and distributed among EPA regional offices and headquarters.

\section{Pertinent Leglsiation}

The Comprehensive Environmental Response, Compensation, and Liability Act [1] (CERCLA, otherwise known as Superfund) and the Resource Conservation and Recovery Act [7] (RCRA) are the principal federal statutes prescribing how the nation's hazardous waste problem will be addressed. While each deals with a different aspect of the hazardous waste issue, both have the same overriding goal-protection of the public health and the environment. CERCLA focuses on remediation of old, usually abandoned, hazardous waste sites. The primary goals of RCRA are to ensure the safe disposal of cumently generated hazardous waste and the environmentally sound operation of waste treatment, storage, and disposal facilities. Amendments to RCRA in 1984 also authorized an extensive corrective action program for RCRA-regulated facilities. This corrective action program closely resembles the CERCLA remediation program in intent and function. (See Appendix A for a more detailed description of CERCLA and RCRA.)

Federal agencies generally are subject to the requirements of CERCLA, RCRA, and relevant state laws on hazardous waste cleanup and operation of facilities handling hazardous waste. The CERCLA program is administered by EPA at the regional level. This means that to clean up a hazardous waste site under CERCLA, DOE must get approval on its process and its documentation from the EPA. Under RCRA, the process is some what more complicated, because RCRA allows EPA to authorize individual states to administer the RCRA program. Because few states have yet been authorized to administer the full program, DOE must often get approval on cleanup activities under RCRA provisions from both EPA and state agencies.

\section{SITE CHARACTERIZATION AND ASSESSMENT}

Before reaching the stage at which a remediation technology can be designed and cleanup decisions can be implemented at a site, existing regulatory and institutional requirements dictate that an extensive planning, characterization, and assessment activity be conducted. This section of the report describes the characterization and assessment activities required to fulfill the regulatory and instiutional requirements, the costs and schedules required to conduct these activities, and the roles and responsibilities of the various paries involved, with emphasis on the role of the public and the courts.

\section{Characterization and Assessment Activities}

Existing regulatory and institutional requirements dictate that an extensive planning, characterization, and assessment activity precede actual site cleanup. This process is referred to as the remedial investigation/feasibility study (RL/FS) process. Under RCRA, the analogous process is called the RCRA facility investigation/corrective measures study (RFI/CMS). The objectives of the activities conducted within these processes are to assess the nature and extent of the environmental problem at a site, identify the regulations and requirements that will be used to guide cleanup, and evaluate the technology altematives and costs proposed for cleanup. An important part of the process is the involvement of regulators and the public in determining the problems at a site and in developing a reasonable solution for cleanup. 
Agreements must be obtained with the appropriate regulatory agencies and public parties before one can proceed. Details on the specific activities required under both CERCLA and RCRA are contained in Appendix B.

This extensive site planning, characterization, and assessment process must be completed before site remediation may begin. The process requires a significant investment of time and money. EPA experience has shown that it may take an average of 6 to 7 years to complete the planning process and reach a decision on how to proceed with site cleanup. Factors that influence the schedule, beyond the nature of the site itself, include the number of participants in the process and the formal reviews required for the major documents. A list of the various documents associated with the process and the specific approvals required for each of these for DOE characterization and assessment activities is provided in Appendix $B$ along with a detailed list of the estimated schedules for DOE sites for each of the activities required in the CERCLA site characterization and assessment process.

The nature of the wastes present at DOE sites complicates the characterization and ultimate cleanup process. Contamination at DOE sites ranges from the standard industrial hazards found at other Superfund sites (solvents, acids, etc.) to a complex mixture of hazardous and radioactive constituents. Most of the release sites are old landfills or trenches used for disposal of vanious materials as long as $\mathbf{4 0}$ years ago, or releases from once-operating facilities that have infiltrated surrounding soil and groundwater at a site. Some release sites, however, are from leaking storage tanks, surface spills or contamination, or special test sites.

The presence of radioactive components at a hazardous waste site creates special problems for DOE during the characterization and assessment process. There are no specific regulations for handling mixed wastes within the CERCLA process. DOE should develop and implement a standard strategy for handling these sites, and gain approval of the approach up front with EPA and other regulatory agencies. Of particular concern will be establishing a sensible approach for setting cleanup criteria on these sites. The sampling and occupational safety considerations for working on a mixed-waste site are more complex than on a site without radioactive constituents. Remediation technologies have not been well developed for mixed-waste sites.

\section{Costs of the Process}

The average cost of completing the RL/FS process ranges from less than $\$ 300,000$ for a small, uncomplicated site to more than $\$ 3$ million for a large, complex site, with the average cost for a single site being around $\$ 1$ million. (a) These figures are based on actual expenditures, to date, at DOD, EPA, and industry sites, and represent the costs incurred by contractors but not agency staff. While information on DOE sites is not yet available because few of the DOE sites have reached a remediation decision at this point, the costs for DOE sites are expected to be 5 to 10 times higher than this average. The primary factors leading to higher costs for DOE sites are 1) the amount and extent of contamination at many of these sites, where a large number of individual release sites are aggregated into an operable unit (the level at which an RL/FS is conducted), and 2) the presence of radioactivity, which is expected to as much as double the complexity of the job relative to DOD. Other factors leading to higher costs include the additional administrative requirements placed on DOE sites and the visibility of the sites.

Table 1 provides information on the average costs of specific activities within the RI/FS process. The elements that are primarily infomation or analysis dniven account for more than $50 \%$ of the cost of an RL/FS. Data on costs for conducting the activities for a RFI/CMS are not yet available, although initial estimates for these activities are similar to those for the CERCLA RI/FS process. ${ }^{\text {(b) }}$

\section{Schedules and Budgets}

The projected schedules for planning and assessment activities at DOE sites are also important to understanding the magnitude of the task ahead. Current schedules for completion of the RI/FS or

(a) Booz, Allen \& Hamilton, Inc. 1988. Final Reponts Vod.I and II., The RI/FS Cost Study. Prepared for the U.S. Environmental Protection Agency, Washington, D.C.

(b) Kissoon, S. May 3, 1989. "Historic Cosss Associated with CERCLA RL/FS Tasks." CH_M Hill Memo w Charlette Geffen, Pacific Northwest Laboratory. 
Table 1. Average Costs for Site Planning, Characterization, and Assessment Activities Based on EPA, DOD, and Private Sector Experience

Project Planning

Community Relations

Remedial Investigation (RI)

Field Investigation

Dala Validation

Dala Evaluation

Risk Assessment

RI Report

Feasibility Study (FS)

Treatability Sudy

Screen Remedial Alternatives

Evaluare Remedial Alternatives

FS Report

Post RI/FS Support

Other

Enforcement Support

Miscellaneous

Expedited Response Actions

TOTAL

$\frac{\operatorname{Cos} s^{(n)}}{\$ 138,000} \quad \frac{\operatorname{Cos} r^{(b)}}{\$ 76,000}$

$17,000 \quad 19,000$

$385,000 \quad 289,000$

$21,000 \quad 24,000$

$30,000 \quad 39,000$

$30,000 \quad 37,000$

$84,000 \quad 100,000$

$37,000 \quad 20,000$

$37,000 \quad 52,000$

$26,000 \quad 31,000$

$74,000 \quad 84,000$

$5,000 \quad 24,000$

$50,000 \quad 129,000$

$40,000 \quad 6,000$

$65.000 \quad 6.000$

$\$ 1,039,000 \$ 936,000$

(a) Booz, Allen \& Hamilton, Inc. 1988. Final Reports Vol. I and II., The RIIFS Cart Study. Prepared for the U.S. Environmental Protection Agency, Washington, D.C.

(b) Kissoon, S. May 3, 1989. "Historic Costs Associaled with CERCLA RIFS Tasks". $\mathrm{CH}_{2} \mathrm{M}$ Hill Memo to Charlette Geffen, Pacific Northwest Laboratory.

RFI/CMS activities for most DOE sites span from 2 to 7 years $^{(a)}$; the schedule required for completing these activities at the Hanford Site is 16 years, with a projected program endpoint for the characterization and assessmenr activities alone of 2005 [8]. For comparison purposes, the schedules anticipated for most of the DOD sites span from 2 to 5 years, with a projected program endpoint, again, for the front-end planning activities alone, of 1995 [9].

(a) U.S. Department of Energy. October 31, 1988. Progran and Implementarion Plan (DRAFT). Defense Programs, Environmental Restoration Program, Washington, D.C.
These timelines assume full program activities are funded in 1989 and do not take into account the very real budget constraints placed on all federal programs. The actual schedules required to complete just these front-end activities for DOE are therefore likely to be even longer based on the available budget and on the new information that is likely to be obtained on different sites.

The budgets currently projected to be required for completing just the planning and assessment portion of the hazardous waste cleanup activities are shown in Table 2.

Table 2. Projected Costs for Characterization and Assessment Activities [10]
Ooerations Office

Albuquerque

Idaho

Nevada

Oak Ridge

Richland

San Francisco

Savannah River
Estimated Budget Needs (\$ Millions)

45.6

103.0

$24.8-32.8$

$143.1-238.2$

$1400.0-2100.0$

31.2

60.0

\section{Partlcipants and Roles}

The planning, characterization, and assessment process for hazardous waste sites involves a number of parties. DOE is responsible for conducting the work and ensuring that activities are performed in a cost-effective, technically credible manner. The planning and assessment activities must also be performed according to the regulations and guidance developed by EPA and the state regulatory agencies. EPA and the state are the primary approval agencies; the major documents produced as part of the planning, characterization, and assessment processes must be approved by them. The public is also included in the review chain for some documents and has the power through the courts to seek judicial review of cleanup decisions which could delay, if not halt, DOE cleanup programs.

Other parties also are critical to DOE's hazardous waste cleanup program. Congress must 
provide the budgetary authorization for DOE programs. Without funding, DOE cannot meet the schedules mandated by the regulations for cleaning up its sites. Operating contractors of DOE facilities and hazardous waste consulting firms are also important as the primary parties through whom DOE accomplishes the tasks supporting site cleanup.

Given the number of parties involved, the visibility of the program, and the potential risks of inadequate documentation, the reports produced as part of these activities are reviewed extensively. This process adds to the time requirements for completing the process. Generally, the data are gathered and documentation completed by the contractors. This material is reviewed by the DOE to ensure it captures local concems, and to provide a consistency and policy check on the work done at each site. The materials are then sent to the regulatory agencies (EPA and the state) for their review and comment. Following this set of reviews, the required documents are put out for public review.

\section{The Role of the Public and the Courts}

The public, Congress, and the courts have taken a lead role in the decision-making process for cleanup of existing waste and prevention of future waste problems. The legal and political issues surrounding hazardous waste have had more impact in this area than the technical issues of site remediation. Recent data about the extent and complexity of environmental problems at DOE facilities have resulted in the agency becoming a highly visible and controversial actor in the hazardous waste arena. This level of attention makes it imperative that DOE fully understand the importance of the planning and documentation required in working through the CERCLA or RCRA processes, and implement these procedures in a consistent way. During the public review process, it is likely that DOE will be required to defend its decisions and respond to a large number of information requests from a vast array of interested, and often adversarial, parties.

The threat of legal action, which could stagnate the cleanup process for DOE, is real. The public will require a credible program from DOE that ensures their protection from hazardous components released through current or past practices.
In addition, the possibility of tort lawsuits against DOE for alleged health damages caused by the operation of its facilities threatens to further complicate cleanup and documentation activities at DOE sites. For instance, such lawsuits have already been filed related to DOE's Fernald, Ohio, plant. Residents near other DOE facilities have complained of health damages related to those facilities and are considering legal action. Recent events also indicate an increased interest by the Deparment of Justice (DOJ) and EPA in pursuing criminal investigations of federal employees and contractors for violations of environmental statutes and regulations.

It is likely that DOE remediation operations will be driven as much by Congressional pressure and legislation as by judicial action. DOE environmental management has become a major political issue, leading to the introduction of several pieces of legislation, public hearings, and statements to the media by members of Congress, all intended to address environmental problems at DOE facilities.

\section{INFORMATION MANAGEMENT: THE MAGNITUDE OF THE PROBLEM}

The information requirements to complete the planning, characterization, and assessment activities for a hazardous waste site can be immense. For example, for the Commencement Bay site in EPA Region X, the remedial investigation report has resulted in an estimated 2500 data records, for each of 15 to 150 variables. ${ }^{(\Delta)}$ For a feasibility study report, this number is expected to double. It is estimated that the average RI/FS report is 1500 pages long, with supporting information housed in rooms of file cabinets. The average administrative record for a site going through the RI/FS process consists of more than 170 linear feet of boxes of paper. $^{(b)}$ This amount of documentation is required to complete the activities for the planning process; supporting data and documentation during actual remediation will likely be much larger. For the Lowry landfill in Denver, Colorado, for example, this involved 45,000 individual documents [11].

\footnotetext{
(a) Personal communicarion with Michael Stoner, Site Manager, Commencement Bay, Environnental Prolection Agency Region $\mathrm{X}$.

(b) Personal communication with Jeff Byron, Superfund Informalion Systems, Environmental Protection Agency.
} 
For complex sites, such as those facing DOE, the amount of information to be managed is likely to be much greater. The Rocky Mountain Arsenal, a DOD facility, is a good example of a complex federal site. The site has six contractors working on different aspects of the planning, characterization, and assessment activities required under CERCLA, and must maintain and integrate data and records collected by each of these contractors. There are approximately 75 documents produced for this activity per year, each document averaging 75 to 100 pages ( 7500 pages per year). The Rocky Mountain Arsenal is renting a warehouse to handle storage of their administrative record files. ${ }^{(k)}$

Many of the DOE sites are as complex as the Rocky Mountain Arsenal. The mixed-waste sites, in particular, present special problems for DOE. The gathering, use, and storage of data are even more important for DOE given the visibility of its sites and the problems it faces in convincing the public that the program is being conducted in a responsible manner. Recent reports of the extent of the DOE hazardous waste problem indicate that there are more than 3600 release sites currently in DOE inventory for Defense Programs alone ${ }^{(b)}$ (DP represents more than $99 \%$ of the problem) $[12,13]$. These release sites are currently grouped into 330 operable units. Site characterization and assessment analysis and documentation activities will be performed under CERCLA or RCRA for each of these operable units. Between major documents required for the process and the backup data and analyses required for the administrative record suppor, DOE could be facing the handling and storage of up to 2.5 million pages of information per year $(7500 \mathrm{pp} / \mathrm{yr} \times 330$ operable units).

\section{INFORMATION MANAGEMENT: THE NATURE OF THE PROBLEM}

The information management challenge presented by waste site cleanup activities is not simply a matter of dealing with the large volume of the data that will be generated. It will also require provisions that consider the complex nature of

(a) Personal communication with K.T. Blose, Chief, Remedial Program Division, Rocky Mountain Arsenal.

(b) U.S. Department of Energy. October 31, 1988. Progran and Implementation Plan (Drafi). Defense Programs, Environmental Restoration Program. Washington, D.C. waste site characterization and assessment activities. To effect solutions that address this complexity, it is important to understand some of the critical components of the problem faced by those who will have to implement and manage cleanup efforts.

The large site data sets needed to make sound decisions in the RI/FS process must be managed. Embodied in the need to manage these large sets of data is a concem of dealing with data of unequal quality. The public needs the confidence that cleanup decisions are being made on the basis of the best data available, and they need assurance that the best data available are of at least a certain quality. The quality assurance and control issue arises from the fact that waste sites will be addressed by a number of individuals residing in different organizations and that sources of data may range from laboratory tests to engineering judgment based on data for similar situations. In collecting and entering data as part of the information base for a site, it will be important to attach a quality level to the data along with an identifier that indicates the data source to provide the credibility in the data that the public and regulatory agencies will demand.

At each stage in the $\mathrm{RI} / \mathrm{FS}$ process, decisions must be made and documented. Because the data set associated with site characterization and cleanup is continually evolving, it is important to be able to track each decision to the data set that was available at the time when the decision was made. Given the scrutiny that each decision is likely to receive by both EPA and the public, it is important to have the documentation readily available to support the decisions that are made.

In addition to managing data generated at a site, there will be a need to efficiently access and link information from diverse data sets in the analysis process. These data sets might include commercial data bases providing information on applicable statutes and regulations, technical information generated at other sites, or technical information produced by different contractors within the same site.

There are a number of specific documents that sites will be required to produce for DOE, EPA, and public comment under the RI/FS 
guidance. The three Federal Facility Agreements [13-15] signed to date by DOE differ in the terminology used to refer to these site characterization documents and in how the administrative review requirements are set for each of these documents. These differences, multiplied across all of the DOE facilities, could create major difficulties for effectively and consistently managing characterization activities on a national scale.

Given the high visibility that DOE waste cleanup activities will receive, the DOE can expect to receive many ad hoc requests for information from a variety of constituencies (Congress, the media, public interest groups, the scientific community, etc.). Regardless of the audience, there will be a need to respond quickly, accurately, and in a format and level of detail appropriate to the audience. A relatively detailed level of information will likely be required for credibility within the technical community, whereas communicating with the public will require that information be aggregated at a much higher level.

It will be extremely difficult to respond quickly to requests for information when that information is maintained at individual sites by a cadre of different contractors. For example, a request could come from Congress to DOE to provide information on the extent of the mixedwaste problem nationwide. Responding to this request currently would require having each site compile data from its various contractors. The information from the individual sites would then have to be integrated by DOE.

A uniform approach to site characterization and assessment activities among contractors within a site and across all sites will instill greater public confidence in the DOE program. The issue of consistency is particularly relevant to

- identifying and screening remediation technologies

- identifying and screening relevant regulations and cleanup criteria

- managing data sets, including validation and quality assurance

- reporting.

While the goal of developing credibility and instilling confidence in the public will be a significant driver of the need for consistency in approach, the importance of conducting the DOE site cleanup program cost effectively and with expediency is also a compelling factor.

\section{OPTIONS FOR DOE}

A technically credible information management system that is applied consistently across all DOE facilities, and that integrates public and regulatory agency concems into the process will enhance DOE's chances for successful execution of the waste remediation program. In designing an approach, the DOE would need to ensure that the information management system enables, rather than burdens, the site characterization and assessment process. In assessing the enabling value of an information management system, the following key questions need to be asked:

- Will the system reduce costs relative to current methods?

- Will the system streamline the process (i.e., save time)?

- Will the system be credible in the technical community and facilitate the communication process so as to instill public confidence in DOE?

- Will the system be applicable regardless of the site characteristics?

The magnitude and complexity of DOE's cleanup problem suggest the need for a standardized approach to planning, characterization, and assessment activities to achieve cost-effective cleanup. In the absence of a standardized approach to information management, the number of contractors and potentially different approaches that could be used to manage the data and information at DOE sites may result in the same problems of inconsistency in cleanup standards, application of remediation technologies, program costs, data quality, and defensibility that have been experienced by EPA. For example, each site and each contractor would develop an approach based on its own perceptions of its immediate needs. This would result in numerous, incompatible systems and considerable duplication of effort. Because of the narrow focus in developing the individual information management systems, it is unlikely that a system tailored to the specific needs of one 
site could be extendable to another site. The resulting lack of compatibility among the various systems would make it difficult to readily access and integrate information from different sites to communicate clearly with the public, Congress, and other influential audiences. This is likely to produce a perception of poor management and a lack of credibility with these groups.

Standardization of information management would greatly facilitate negotiations with the regulatory agencies and the public, as well as minimize duplication of costs among sites and contractors in this area. More specifically, standardization should be required among sites with respect to how information is stored, what information sources are used, and how information is used to make key decisions such as identifying cleanup criteria and screening technologies. In addition, standardization of reporting information, at least for the documents required by the RLFS guidance, would be useful. If DOE receives the same types of reports from each of the sites in the same format, DOE and EPA staff will be able to conduct their reviews more quickly, thus streamlining both the review schedule and the cost.

EPA's experience reveals clearly the need for coordination of site planning, characterization, and assessment activities at the national level. While there is a need for centralized coordination, the issue of how much of the information management function should be centralized continues to be discussed. Although a centralized approach would, in theory, enable communications that require aggregating data from various sites, in reality this would be highly dependent on the ability of the sites to compile and submit information in a timely manner and on the proinpt entry of this information into the central data base. The cost effectiveness of this approach is also questionable given that each site would still need to maintain its own data base in addition to the one centrally maintained. The dual systems would also exacerbate the data quality issue, particularly if the site systems and the central system contain differing information as a result of data entry errors or differences in the timing of system updates. These differences would again raise questions of credibility. The main disadvantages of decentralized systems are 1) a tendency for each site to "reinvent the wheel," which can be costly, and 2) the barriers that site-specific systems will present for sharing information among sites.

The most effective information management system will most likely combine centralized elements with others that are decentralized to the individual sites. Centralized management of the standards for the format and quality assurance of all information in the system is required in any case. The benefits of this type of approach are that it addresses the DOE's need to quickly compile and provide information on cleanup activities while providing the sites with the flexibility to manage information within the established guidelines to meet their own specific needs. In addition, cost savings can be realized through the efficient transfer of experience (e.g., what technologies worked or didn't work) among the sites.

Through automation an opportunity exists to combine the best features of a centralized and a decentralized approach. With an automated system, each site would maintain its own site-specific information in a standardized format that would facilitate retrieval and integration with data from other sites. Central data bases would contain information relevant to all sites (regulations, cleanup criteria, technology data). An on-line system could be provided to enable the sites to access the central data bases and query the individual site data bases from a central source to facilitate compiling cross-site reports. This would enable DOE to respond to ad hoc requests for information more quickly and with assurance that the data are consistent with what is being reported by the sites.

\section{CONCLUSIONS}

By establishing a technically credible information management system and applying it consistently across all sites, DOE could avoid many of the problems that have been encountered by the EPA. Information management should be included explicitly as an element in the DOE site remediation planning process. Through up-front planning, the expense of attempting to effect a uniform. information management system after numerous, diverse systems have been put into place at the individual sites and by individual contractors within sites could be avoided. 
A site remediation information management system will benefit DOE by

- ensuring that a uniform approach is taken across and within sites with respect to data validation and quality assurance, decision making and decision documenting, and reporting

- providing efficient access to and sharing of information among sites to facilitate knowledge and technology transfer and to avoid costly duplication of effort

- enabling timely and credible responses to requests for information that require compiling information across sites from a variety of constituents (e.g., Congress, the media, public interest groups).

Such a system would support the conduct of DOE's site remediation program in a cost effective and expedient manner while facilitating efforts to instill public confidence in the program.

\section{REFERENCES}

1. Comprehensive Environmental Response, Compensation, and Liability Act (CERCLA) of 1980. Public Law 96-510, as amended.

2. U.S. General Accounting Office. July 1987. Superfund: Civilian Federal Agencies Slow to Clean Up Hazardous Waste. GAO/RCED-87153, B-215824. Washington, D.C.

3. Reilly, William K. 1989. A Management Review of the Supe fund Program. 623-682/ 10263. U.S. Environmental Protection Agency, Washington, D.C.

4. Crawford, Mark. June 1988. "Superfund Program Under Fire." Science. 240:1725.

5. Heil, Jeffrey and James Van Blarcom. July 1986. "Superfund: The Search for Consistency." Hazardous Waste. p. 2-5.

6. U.S. Govemment Accounting Office. July 1988. Superfund Contracts: EPA Needs to Control Contractor Costs. GAO/RCED-88182. Washington, D.C.

7. Resource Conservation and Recovery Act (RCRA) of 1976. 42 U.S.C. 6901 , as amended.
8. Proposed Action Plan for Implementation of the Hanford Federal Facility Agreement and Consent Order. February 27, 1989.

9. Defense Plant Wastes. April 14, 1989. p. 60.

10. U.S. Department of Energy. December 1988. ES\&H Needs Assessment Report, Vol. 2, DOE/ EH-0079. Washington, D.C.

11. Willians, Gary. May 31, 1989. "Technology Today." Presented at Information Technology and Environmental Issues: Opportunity for Growth and Profit in the 1990's. Automated Compliance Systems, Inc., Bridgewater, New Jersey.

12. U.S. Department of Energy. December 1988. ES\&H Needs Assessment Report, Vol. 1. DOE/ EH-0079. Washington, D.C.

13. Tri-Party Agreement. 1989. Hanford Federal Facility Agreement and Consent Order Between the U.S. Environmental Protection Agency, the U.S. Department of Energy, and the State of Washington Deparment of Ecology, May 15, 1989. U.S. Department of Energy, Richland Operations Office, Richland, Washington.

14. U.S. Environmental Protection Agency, Region VIII, The State of Utah Department of Health, and The United States Department of Energy. December 1988. Federal Facility Agreement Pursuant to CERCLA Section 120.

15. U.S. Environmental Protection Agency, United States Department of Energy, Califomia Department of Health Services, and Califomia Regional Water Quality Control Board. November 1988. Federal Facility Agreement Under CERCLA Section 210. 


\section{APPENDIX A DESCRIPTION OF CERCLA AND RCRA}





\section{APPENDIX A: DESCRIPTION OF CERCLA AND RCRA}

The Comprehensive Environmental Response, Compensation, and Liability Act (CERCLA) establishes a statutory framework to govem the cleanup of existing, and often abandoned, hazardous waste sites. CERCLA is a liability based statute in that those responsible for the hazardous waste at a site are also responsible for the cost of cleaning up the site. The potentially responsible parties (PRPs) could include the original generators of the waste, the parties who transported the waste to the site, and the site owner. Federal agencies must meet the same requirements as PRPs. CERCLA itself generally does not establish specific cleanup standards, but references other environmental statutes, regulations, and guidance documents for specific remediation levels.

CERCLA also established a fund to finance the cleanup of sites where responsible parties cannot be identified or located or are unable to fund such activity. For the most part, this fund cannot be used to clean up sites owned by federal agencies. These sites generally must be remediated using the agencies' own appropriated funds.

CERCLA was initially authorized in 1980. In 1986, the Superfund Amendments and Reauthorization Act (SARA) amended the original CERCLA law. Among other things, SARA clarified the federal govemment's enforcement powers under CERCLA, expanded the size of the site cleanup fund, and expanded the scope and nature of health studies to be conducted at hazardous waste sites and on hazardous substances.

Federal agencies are subject to the requirements of CERCLA and must comply with relevant state laws relating to hazardous waste cleanups, as specified in section 120 of CERCLA (42 U.S.C. 9620). This section also states that cleanup criteria chosen for a federal facility must be consistent with those standards established by the U.S. Environmental Protection Agency (EPA).
The Resource Conservation and Recovery Act (RCRA), originally authorized in 1976, mandates a "cradle-to-grave" regulatory scheme that tracks hazardous waste from its generation to its ultimate storage or disposal. All treatment, storage, and disposal (TSD) facilities are required to obtain a permit to operate. As with CERCLA. the federal govemment is required to comply with RCRA requirements and relevant state laws, which means all federal facilities that handle hazardous waste must be permitted in accordance with RCRA.

The amendments to RCRA in 1984 established an extensive corrective action program, similar to the CERCLA remediation process, to address releases of hazardous substances to the environment from permitted TSD facilities. This corrective action program is intended to address releases from RCRA facilities that pose a risk to public health or the environment. EPA has drafted detailed regulations, not yet approved, that will set forth the requirements of the corrective action program.

Because of the similar goals of each of the statutes, there exists substantial overlap between the requirements of the RCRA corrective action program and the CERCLA program. Frequently, specific sites or facilities could be remediated under either program. With respect to federal facilities, the decision conceming which regulatory program to use to address a site normally involves several factors. Sites associated with currently operating facilities nomally will be subject to RCRA corrective requirements. "Abandoned" sites or spill sites not associated with a currently operating facility usually will be addressed under CERCLA. Often, such decisions are largely political and are the result of negotiations between the federal and state regulatory agencies and the responsible federal parties. 


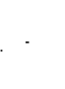




\section{APPENDIX B}

\section{DESCRIPTION OF RI/FS ACTIVITIES}




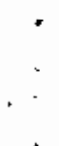

* 


\section{APPENDIX B: DESCRIPTION OF RI/FS ACTIVITIES}

The CERCLA process (see Appendix A for complete definition), as designed by Congress and implemented by the EPA, includes an intensive planning process to ensure that the cleanup action eventually implemented at a site will provide a permanent remedy for environmental protection. An important part of the process is the involvement of regulators and the public in determining the problems at a site and developing a reasonable, effective cleanup approach. This involvement is mandated through a series of planning and documentation steps that are presented in EPA's regulations and guidance. This planning process normally must be accomplished before actual site cleanup can begin. The process for remediation under the RCRA corrective action provisions is very similar to the activities required to be conducted under CERCLA. While the names of the steps of the process are different under the RCRA and CERCLA programs, the goals and activities are roughly parallel. For simplicity, only the CERCLA process is discussed here, and only the CERCLA terminology is used.

The activities that must be conducted under CERCLA before the design and implementation of a cleanup action can begin fall into three basic categories: 1) scoping studies, 2) characterization and assessment investigations, called remedial investigation/feasibility studies (RL/FS), and 3) decision making. Each of these activities is briefly discussed below.

The purpose of the scoping process is to plan and prioritize the characterization and assessment work that is to be conducted at a hazardous waste site. The main objectives of the scoping process are to

- determine the types of decisions to be made

- identify the type and quality of data needed to support those decisions

- describe the methods by which the required data will be obtained and analyzed

- prepare project plans to document methods and procedures.
A project plan is required to document the scoping activities. This plan, which must be approved by EPA, describes the specific plans and procedures to be used for a particular site or set of units in conducting the RI/FS process. It is a detailed document that includes a Sampling and Analysis Plan, Health and Safety Plan, Community Relations Plan, Data Management Plan, Project Management Plan, and Technology Plan.

Once the initial scoping activities have been completed, and a project plan is approved by DOE and EPA, the characterization and assessment activities begin. These activities are divided, under regulation and EPA guidance, into two processes, remedial investigation (RI) and feasibility study (FS). Development of the RL/FS is an iterative process and usually involves a number of different phases.

The remedial investigation focuses on site characterization activities. Field investigations are conducted to define the nature and extent of contamination (characterize waste types, concentrations, and distributions). Based on these investigations, the initial cleanup goals are determined.

Cleanup goals are developed based on an analysis of relevant environmental regulations. The issue of developing applicable, relevant, and appropriate requirements (ARARs) is complicated, but very important, because it is by these regulations and standards that EPA will judge the acceptability of final cleanup options and actions.

The purpose of the feasibility study process is to develop and screen alternative technologies and approaches for cleaning up the site. These activities include identifying potential remedial altematives, performing treatability studies to ensure remedial technologies will operate as expected in the field, and selecting recommended alternatives. These potential technologies are then screened against the remedial action objectives and the ARARs to determine their suitability. If all the requirements are met, the potential technologies are then written into the altematives. 
Remedial altematives are selected based on the following criteria: effectiveness, implementability, and cost (between equally effective altematives). The altemative selected must, anong other things, protect human health and the environment; attain the applicable ARARs; reduce toxicity, mobility, or volume; and be technically reliable. The selection of techmologies must also consider monitoring, maintenance, and possible replacement activities for post-cleanup. The costs of these operations must also be considered. This information is presented in the FS report.

The final steps of the planning process are concluded in the decision documents: Proposed Plan and Record of Decision. The primary purpose of the proposed plan is to communicate the highlights of the RI/FS report to the public. The proposed plan provides a brief analysis of the remedial altematives that were considered and identifies the preferred altematives. It also discusses the mechanisms by which the public can participate in the remedial selection process.

The Record of Decision (ROD) document summarizes the site problems and analyzes remedial altematives. It explains the rationale for the lead agency's selection of a preferred altemative. The document must also include a section that provides lead agency decision makers with information about community preferences regarding remedial altematives and general site concems. It must also outline for the public how their comments were taken into account as an integral part of the decision-making process.

This extensive planning process, which must be completed before actual site remediation may begin, requires a significant investment of agency time and money. Each of the major documents associated with this process must be reviewed within the agency as well as by the regulatory agencies for approval. Some of these documents must go through a formal public review and comment procedure. Table B. 1 shows the EPA/ state and public involvement required at each point in the process. A major effort is required to conduct the planning, characterization, and assessment work; produce the required documents with high quality and retrievable data; and obtain the required reviews. Depending on the complexity of a given site, approximately 6 to 7 years will be necessary to complete this planning process and obtain agreement on an ROD (approval to proceed with site remediation) at most DOE sites. This process could require more time for more complex sites. A general schedule showing the anticipated approximate timeframes for each of the activities required in the CERCLA RL/FS/ROD process at DOE sites is provided in Figure B.1.

Additional information on CERCLA and RCRA activities can be obtained from the following references:

1. U.S. Environmental Protection Agency. CERCLA Compliance with Other Environmental Starutes. OSWER 9234.0-02.

2. U.S. Environmental Protection Agency. Guidance for Conducting Remedial Investigations and Feasibility Studies Under CERCLA. OSWER 9355.3-01.

3. U.S. Environmental Protection Agency. RCRA Facility Investigation Guidance. EPA 530/SW87-001.

4. U.S. Environmental Protection Agency. RI/FS Improvements. OSWER 9355.0-2. 
Table B.1. EPA/State/Public Involvement (OSWER 9355.3-01)

\begin{tabular}{|c|c|c|}
\hline Activity & EPASState & Public \\
\hline Scoping & Meetings & $\begin{array}{l}\text { Community interviews; } \\
\text { write CRP }\end{array}$ \\
\hline Project Plan & $\begin{array}{l}\text { Review \& comment on } \\
\text { draft project plan ( } 30 \text { days) }\end{array}$ & Informal comment \\
\hline Site Characterization & Briefings/meetings & Briefings/meetings \\
\hline Develop \& screen alternatives & Briefings/meetings & $\begin{array}{l}\text { Briefings/meetings } \\
\text { (informal comment) }\end{array}$ \\
\hline Treatability Study Work Plan & Review \& comment ( 30 days) & Briefings/meetings \\
\hline Treatability Investigations & Briefings/meetings & Briefings/meetings \\
\hline $\begin{array}{l}\text { Treatability Test Evaluation } \\
\text { Report }\end{array}$ & Review \& comment ( 30 days) & Briefings/meetings \\
\hline $\begin{array}{l}\text { Detailed analysis of } \\
\text { selected alternatives }\end{array}$ & Briefings/meetings & $\begin{array}{l}\text { Briefings/meetings } \\
\text { (intormal comment) }\end{array}$ \\
\hline Draft RI/FS Report & Review \& comment ( 30 days) & $\begin{array}{l}\text { Briefings/meetings } \\
\text { (informal comment) }\end{array}$ \\
\hline Revised RI/FS Report & Review \& comment ( 30 days) & Briefings/meetings \\
\hline Proposed Plan & $\begin{array}{l}\text { Comment, formal DOE response } \\
\text { ( } 30 \text { days). Finalize proposed plan, } \\
\text { summarize comments }\end{array}$ & $\begin{array}{l}\text { Official comment } \\
\text { (21 days) }\end{array}$ \\
\hline $\begin{array}{l}\text { ROD \& Responsiveness } \\
\text { Summary (RS) }\end{array}$ & $\begin{array}{l}\text { Draft ROD, RS to EPAState, } \\
\text { obtain EPA administrator } \\
\text { concurrence }\end{array}$ & $\begin{array}{l}\text { Publish notice of ROD } \\
\text { \& RS; make available } \\
\text { before starting } \\
\text { response action }\end{array}$ \\
\hline
\end{tabular}




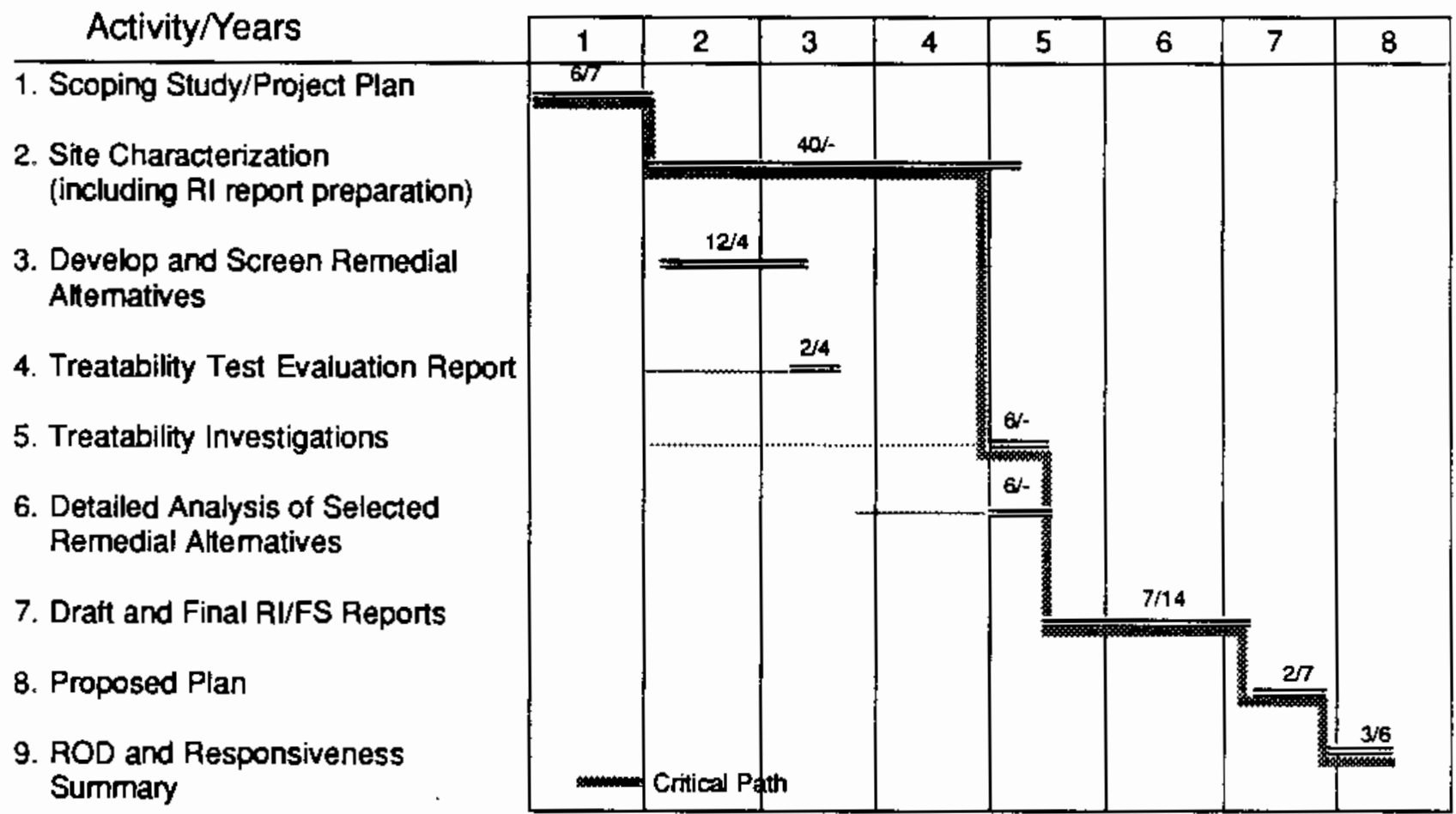

Nole: 67 moans 6 months tecthical work and 7 months review, revision, etc.

Figure B.1. General Activity Schedule Supporting ROD 


\section{DISTRIBUTION}

No. of

Copies

OFFSITE

2 DOE/Oflice of Scientific Technical Information

C. Ariss

Idaho National Engineering Laboratory

P.O. Box 1625

Idaho Falls, ID 83415

W.L. Scott

Idaho National Engineering Laboratory

P.O. Box 1625

Idaho Falls, ID 83415

L. Timmey

EG\&GIEM

P.O. Box 1912

Las Vegas, NV 89125

M. Vannoni

Sandia National Laboratories

ORG. 6321

P.O. Box 5800

Albuquerque, NM 87185

J.W. Formento

Argonne National Laboratory

EAIS -362-3F

9700 Scass Ave.

Argonne, IL 60439

A.P. Campbell

Argonne National Laboratory

EAIS-362-3F

9700 Scass Ave.

Argonne, IL 60439
No. of

Copjes

Dr. K. Drake

MS E535

Los Alamos National Laboratory

Los Alamos, NM 85745

C. Williamson

Science/Engineering Education Div.

Oak Ridge Associated Universities

Oak Ridge, TN 37830

ONSITE

4 DOE Bichiand Operations

J.J. Sutey

D.E. Trader (2)

D.K. Jones

57 Pacific Northwest Laboratory

R.C. Adams

M.P. Bergeron

C.R. Cole

C.E. Cowan (2)

J.W. Falco

B.A. Garrett (2)

C.A. Geffen (10)

M.J. Graham (20)

J.F. Keller (2)

W.W. Laity

J.R. Lewis

R.C. Liikala

M.R. Siegel (5)

R.L. Skaggs

S.C. Slate

S.L. Stein

Publishing Coordination

Technical Report Files (5) 
+
+
1 